\title{
Mathematical Reasoning in Mathematics Learning on Pyramid Volume Concepts
}

\author{
Ulvatun Niswah ${ }^{1, a}$, Abd. Qohar ${ }^{1, b^{*}}$ \\ ${ }^{1}$ Department of Mathematics Education, Universitas Negeri Malang, Malang, Indonesia, 65145 \\ *Corresponding author: ${ }^{\mathrm{b}}$ abd.qohar. fmipa@um.ac.id | Phone Number: +6281555600400
}

\section{ARTICLE HISTORY}

Received : 13 March 2020

Revised : 26 February 2020

Accepted : 8 April 2020

\section{KEYWORDS}

Mathematical Reasoning; Pyramid Volume;

Learning Process Standard;

\begin{abstract}
The purpose of this study was to describe the standard process of mathematical reasoning in learning on pyramid volume concepts. The study was a study with descriptive qualitative approach, carried out by peer teaching in the classroom. The subjects of this research were Class B Postgraduate 2018 (S2) students, State University of Malang. The standard process of this activity was to recognize reasoning and verification as a basic aspect in mathematics, to make and investigate mathematical conjecture, to find out how to develop and evaluate mathematical arguments and verification, to find out how to choose and use various types of reasoning and proof methods.
\end{abstract}

\section{INTRODUCTION}

Mathematics is formed as a result of human thought related to ideas, processes, and reasoning. Mathematics subject needs to be given to all students as a basis for increasing their ability to think logically, analytical, systematically, critically as well as working skill (Depdiknas, 2006). In school mathematics, the process of reasoning and verification is required to be present in all curricula (NCTM, 2000). Realizing the importance of mathematics, it is considered necessary to be understood and mastered by all people, especially elementary school students to college students.

Based on the results of a survey conducted by the Programme for International Student Assessment (PISA), the ability of student mathematical literacy in Indonesia is still low. Indonesia is located at the bottom of the international average. According to Niss (Kusumah, 2010), one of the basic abilities of mathematical literacy is reasoning and mathematical thinking. Thus, good mathematical reasoning is very necessary to improve mathematical literacy ability. Besides as one of the basic abilities in mathematical literacy, reasoning is also one of the five standard NCTM processes, namely the standard of problem solution, communication, connection, and representation (NCTM, 2000). Reasoning has an important role in mathematics because it is used as a foundation for other standard processes. Besides, reasoning and mathematics cannot be separated because solving mathematics problems needs reasoning, while the ability of reasoning can be trained by learning mathematics.

Mathematical reasoning and verification provide powerful ways to develop and express insights about various phenomena. People whose reasoning and thinking are analytical tend to note patterns, structures, or order in both real world situations and symbolic objects. They ask whether the patterns are intentional or happen for a reason and they speculate and verify. In the end, mathematical evidence is a formal way of expressing certain - types of reasoning and evidence. In response to this, the government created a curriculum that was compiled by and implemented in each education unit. The curriculum program has been and is still being used as a vehicle to do reformation (Van Steenbrugge \& Ryve, 2018).

Mathematical reasoning includes logical ability, and systematic thinking. According to Brodie (2010:9), mathematical reasoning is a thought process that connects a new knowledge with existing knowledge, and then rearranges the knowledge acquired. Meanwhile, according to Suparno et al (2006: 41) reasoning is a process of thinking systematically and logically to obtain a conclusion (knowledge or belief). (Gouet et al., 2020) examines the existence of a causal relationship from intuitive (non-symbolic) to symbolic proportional reasoning, Whereas (Paliwal \& Baroody, 2020) fostering the learning of subtraction concepts and the subtraction-as-addition reasoning strategy. From the description above, it can be concluded that reasoning is a thought process in determining a conclusion of a new knowledge received by relating it to the knowledge that has been previously owned.

In the previous study that is associated with mathematical reasoning, Mikrayanti (2016) in her journal entitled Improving the Ability of Mathematical Reasoning through Problem Based Learning describes that there are differences in the increase in the ability of mathematical reasoning between students who receive problem-based learning with students getting conventional learning at the high, medium and low school levels. The numerical difference is seen in the greater average gain in the experimental class than that in the control class for the three school categories. This indicates that problem-based learning can improve students' mathematical reasoning abilities. In another study, (Thuneberg et al., 2018) examined with results that visual reasoning contributed to students' cognitive abilities in STEAM. (Walkington et al., 2019) found 
that students were accustomed to expressing their mathematical reasoning through written notation rather than verbal language accompanied by action. Whereas (Spruijt et al., 2020) states that good parent and child interaction can influence their questioning style, so that it can be beneficial for increasing children's reasoning abilities.

This article is going to discuss about the standard process of mathematical reasoning in learning the pyramid volume material. According to NCTM (2000) there are four standard processes of mathematical reasoning, namely: (1) recognizing reasoning and verification as basic aspects in mathematics, (2) knowing how to make and investigate mathematical assumption, (3) development and evaluation of mathematical arguments and verification (4) selecting and using various types of reasoning and verification methods.

\section{RESEARCH METHOD}

This research was a qualitative descriptive study, which aimed at describing the standard process of mathematical reasoning in learning mathematics in pyramid volume material. Researchers designed learning and then applied it in peer teaching. The subjects of this study were Class B Postgraduate students intake 2018, State University of Malang. The lesson plan was made for one meeting with duration 90 minutes. There were three activities in this study, namely: opening activities, core activities and closing activities. The instruments in the study were RPP (lesson plan) and LKS (student worksheet) which contained pyramid volume material. The working process used the standard process of mathematical reasoning in learning mathematics. In the implementation of peer teaching activities students were divided into two groups. Each group consisted of 4-5 students. The lesson plans and the application were reviewed and analyzed. The results of the analysis discussed were associated with theories that were relevant to the discussion.

\section{RESULTS AND DISCUSSION}

Results and discussion here are going to describe the standard process in the lesson plans and the implementation. The teacher's activities during learning could be said to be in accordance with the lesson plan (RPP) that had been prepared previously. In the opening activity, the teacher greeted students and asked students to start learning by praying. Then the teacher checked the student attendance. After the students were ready to start learning, the teacher reviewed plane figure material which was a prerequisite one for the material to be learned. Then the teacher formed students into 2 groups, and each group consisted of 3-4 students. In the core activity, students began working on the student worksheets given by the teacher with a group that had been determined with guidance from the teacher.

There were four standard processes of mathematical reasoning that had to appear in the lesson plan and its implementation. The standard processes can be seen as follows: In lesson plan and the implementation, the first standard process was to recognize reasoning and verification as the basic aspects in mathematics applied to the activities in which students were given inducement questions by the teacher about pyramid. It also happened when the students observed and completed the activity on the student worksheet. The example is in the activities of Figure 1 below:
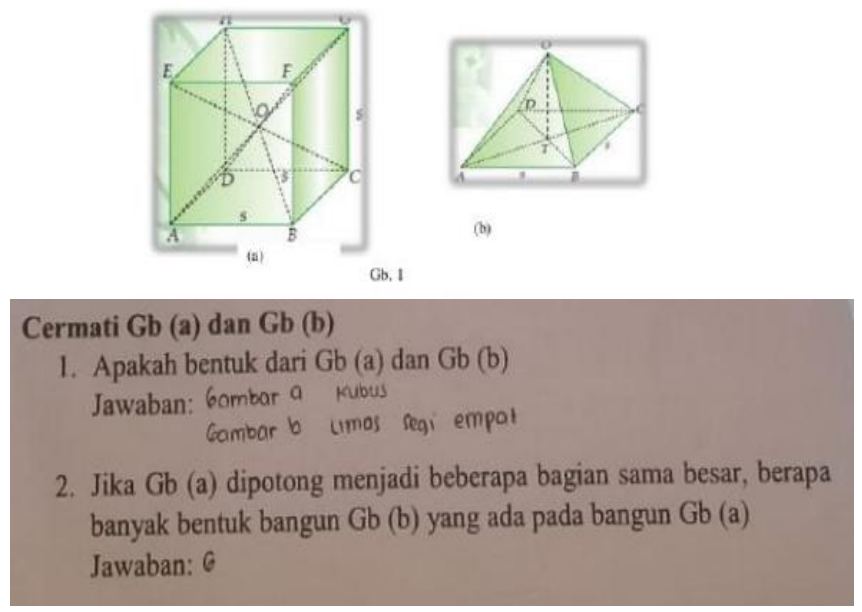

Figure 1. The result of Student Work on Activity 1

In the activities above, the students were expected to be able to use mathematical reasoning in observing solid figure in the cube (Figure A) and also a lot of solid figures in it. Thus, students were expected to be able to observe that in the cube there were 6 square quadrilateral pyramids which had the same peak points. The observation would later be used to determine the formula of the pyramid volume.

According to Ball \& Bass (2003) during the reasoning process, there are two types of actions taking place, namely finding and justifying. In the finding process, new knowledge is investigated and explained. The students are asked to observe and find the type of figure in the cube along with the numbers, and for justification, it will be obtained when students present the each group's answers in front of the class. Meanwhile, according to Rips (1994) reasoning is the process of generating a new knowledge from the previous experience. It means students are guided from the previous experience that is before learning pyramid students are first taught about cubes and other plane figure in the opening activity. Thus, students have gained knowledge from the volume of the cube and been developed to search for a new knowledge by finding the pyramid volume through cube.

The second standard process was to make and investigate mathematical assumptions applied to the activities where students made assumptions of the existing activities. The example is in the activity in Figure 2 below:

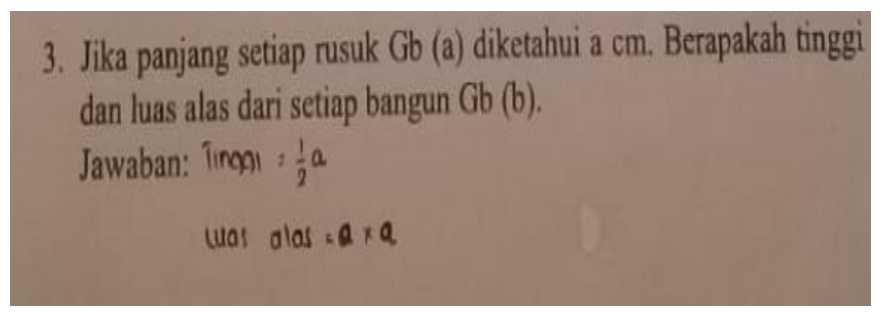

Figure 2. Student Work Results in Activity 1

In the activities above, the students were expected to be able to make conjecture in the form of what the height and area width of the figure in the cube were. Because the cube had same sides, if the side was considered as length $a$, then the height of the cube was $a$, whereas for the solid figure inside the cube, namely a quadrilateral pyramid had a half-length from the cube because we could observe that the peak point of each solid 
figure was in the middle. It means that the height of the regular quadrilateral pyramid was $1 / 2$ of the height of the cube, which was $1 / 2$ a.

According to Ball \& Bass (2003) during the reasoning process, there are two types of actions taking place, namely finding and justifying, in the process of finding, a new knowledge is investigated and explained. In the second standard process in this study the students were guided to find and investigate whether the height of the pyramid was $1 / 2$ the height of the cube.

The third standard process was the development and evaluation of mathematical arguments and verification applied to the activities in Figure 3 below:

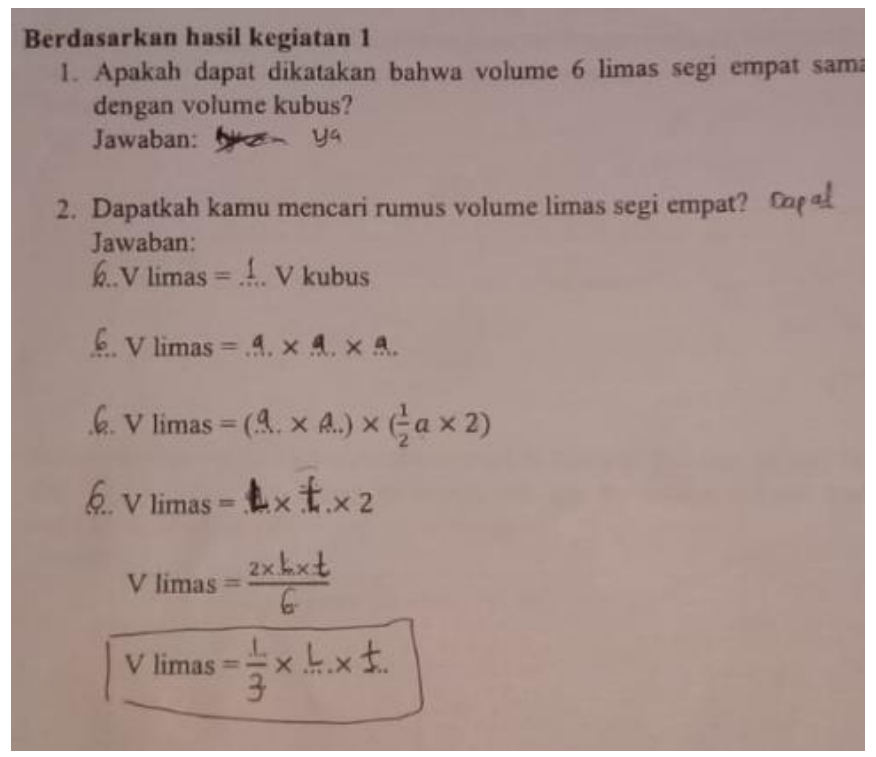

Figure 3. Student Work Results in Activity 2

In the activities above the students were expected to be able to develop a formula of the pyramid volume of a cube that was already known. Students were not only guided to develop, but also to find and investigate at once because the students had to find the formula of the pyramid volume based on the cube volume in which the students could get from the previous activities from the pictures they had observed. Thus, when inside the cube there were 6 same pyramids, the volume of the 6 pyramids would be the same as the volume of the cube. The evaluation occured when students made presentations and other groups responded and afterwards the teacher gave reinforcement and reflection.

The final standard process was to select and use various types of reasoning and verification methods applied to the activities in Figure 4 below:

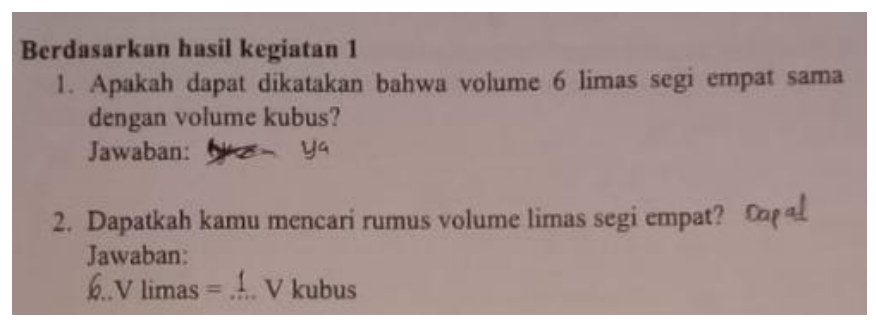

Figure 4. Student Work Results in Activity 2

Reasoning can be defined as a coordinated process of evidence, beliefs and ideas resulted from the conclusion of reality (Leighton, 2003). From Figure 1 above, the students could choose and use various types of reasoning that were considered easy that could be used to solve various questions through the pictures in student worksheet and also when working on exercises after group discussion. Students were guided to have logical reasoning from simple and developed things. In addition to the above activities, this standard process was also needed when students worked on problems related to daily life in activity 3 .

\section{CONCLUSION}

From the learning activities carried out, it can be concluded that in learning process, student mathematical reasoning always emerges. It can be seen that one of them is based on the indicators of standard process of mathematical reasoning in NCTM, namely (1) recognizing reasoning and verification as basic aspects of mathematics that arise when observing the figures in the cube (Figure a) and also many existing figures in it, (2) knowing how to make and investigate mathematical conjectures that arise when students make conjectures what the height and area of the base of the figure in the cube are, (3) the development and evaluation of mathematical arguments and verification that arise when students develop pyramid volume formula from the known cube volume, (4) selecting and using various types of reasoning and verification methods that arise when students choose and use various types of reasoning that are considered easy that can be used to solve various questions through pictures in the worksheet and when students work on exercises after group discussion.

Learning with problem solving approach can improve the ability of mathematical understanding and student mathematical reasoning. Therefore, it is suggested to the teachers that the problem solving approach is a solution and an alternative in improving students' mathematical understanding and reasoning abilities.

In the implementation of learning in the classroom the teacher should be able to make the students mutually work together to resolve the problem that is given. Teachers of mathematics are also expected to create harmonic conditions so that the students are able to express arguments with their own language of as well as perform more confidently in presenting their ideas.

\section{REFERENCES}

Ball, D.L., \& Bass, H. (2003). Making mathematics reasonable in school. In J. Kilpatrick, W. G. Martin. \& D. Schifter. (Eds.), A research companion to principles and standards for school mathematics (pp. 227-236). Reston, VA: National Council of Teachers of Mathematics.

Brodie, K. (2010). Teaching Mathematical Reasioning in Secondary School Classrooms. New York: Springer

Depdiknas. (2006). Kurikulum Tingkat Satuan Pendidikan. Jakarta : Depdiknas.

Gouet, C., Carvajal, S., Halberda, J., \& Peña, M. (2020). Training nonsymbolic proportional reasoning in children and its effects on their symbolic math abilities. Cognition, 197(November 2017), 104154. https://doi.org/10.1016/j.cognition.2019.104154

Kusumah, Y. S. (2010). Literasi Matematika. In Prosiding 
Seminar Nasional Pendidikan MIPA. Lampung.

Leighton, J. P. (2003). Defining and describing reasoning. In J. P. Leighton \& R. J. Sternberg (Eds.), The nature of reasoning (pp. 3-11). New York, NY: Cambridge.

Mikrayanti. (2016). Meningkatkan Kemampuan Penalaran Matematis melalui Pembelajaran berbasis Masalah, Suska Journal of Mathematics Education, Vol 2 (2), 97 - 102

Paliwal, V., \& Baroody, A. J. (2020). Early Childhood Research Quarterly Fostering the learning of subtraction concepts and the subtraction-as-addition reasoning strategy. Early Childhood Research Quarterly, 51, 403-415. https://doi.org/10.1016/j.ecresq.2019.05.008

Rips, L. J. (1994). The psychology of proof: Deductive reasoning in human thinking. Cambridge, MA: MIT.

Spruijt, A. M., Ziermans, T. B., Dekker, M. C., \& Swaab, H. (2020). Journal of Applied Developmental Psychology Educating parents to enhance children's reasoning abilities : A focus on questioning style. Journal of Applied Developmental Psychology, 66(March 2019), 101102. https://doi.org/10.1016/j.appdev.2019.101102

Suparno \& Yunus, M. (2006). Keterampilan Dasar Menulis. Jakarta: Universitas Terbuka.

The National Council of Teachers of Mathematics (NCTM). 2000. Principles and Standarts for School Mathematics. Amerika Serikat. The National Council of Teachers of Mathematics, Inc.

Thuneberg, H. M., Salmi, H. S., \& Bogner, F. X. (2018). How creativity, autonomy and visual reasoning contribute to cognitive learning in a STEAM hands-on inquiry-based math module. Thinking Skills and Creativity, 29(July), 153-160. https://doi.org/10.1016/j.tsc.2018.07.003

Van Steenbrugge, H., \& Ryve, A. (2018). Developing a reform mathematics curriculum program in Sweden: relating international research and the local context. ZDM, 50(5), 801-812.

Walkington, C., Woods, D., Nathan, M. J., Chelule, G., \& Wang, M. (2019). Does restricting hand gestures impair mathematical reasoning? Learning and Instruction, 64(June 2018), 101225. https://doi.org/10.1016/j.learninstruc.2019.101225 